\title{
Educational Research Within the Curricula of Initial Teacher Education: The Case of Slovenia
}

TINA ŠTEMBERGER ${ }^{1}$

$\approx$ Professional learning is a continuum starting in initial teacher education and persisting throughout the teacher's career. Initial teacher education programmes should therefore prepare prospective teachers for professional learning via research. There is, however, little knowledge about how initial teacher education programmes educate students about this important subject. The aim of this study was to identify how initial teacher education programmes in Slovenia address the question of empowering prospective teachers with research competence. We analysed all of the initial teacher education programme curricula and established that: (i) overall, more than half of the initial teacher education programmes do not include acquiring research competence as an aim of their study programmes; (ii) the majority of bachelor initial teacher education programmes include courses aimed at gaining research competence, but half of the master's initial teacher programmes do not provide any courses related to research; and (iii) there is a variety of European Credit Transfer and Accumulation System weightings for educational research courses across initial teacher education programmes in Slovenia.

Keywords: initial teacher education, research competence, educational research

1 Faculty of Education, University of Primorska, Slovenia; tina.stemberger@pef.upr.si. 


\section{Pedagoško raziskovanje v programih začetnega izobraževanja učiteljev v Sloveniji}

TinA ŠTEMBERgER

Učiteljev poklicni razvoj se začne v okviru začetnega izobraževanja in se nadaljuje skozi celotno profesionalno pot. Programi začetnega izobraževanja naj bi zato prihodnje učitelje opolnomočili za profesionalno učenje prek raziskovanja, vendar pa je to področje šibko raziskano in zato slabše poznano. Cilj te študije je bil ugotoviti, kako programi začetnega izobraževanja naslavljajo raziskovalno kompetenco. Na podlagi analize vseh programov začetnega izobraževanja v Sloveniji je bilo ugotovljeno: i) da v splošnem več kot polovica teh programov ne vključuje raziskovalne kompetence kot učnega izida; ii) da večina dodiplomskih študijskih programov vključuje predmete, $\mathrm{v}$ okviru katerih naj bi študentje pridobili raziskovalno kompetenco, hkrati pa kar polovica magistrskih študijskih programov takšnega predmeta ne predpisuje; iii) da je predmetom, ki razvijajo raziskovalno kompetenco, namenjenih zelo različno število kreditnih točk.

Ključne besede: začetno izobraževanje učiteljev, raziskovalna kompetenca, pedagoško raziskovanje 


\section{Introduction}

In modern societies, which are characterised by constant and rapid change, the roles of teachers are becoming increasingly demanding, thus giving rise to a need to enable teachers to cope with the complexity of these demands and needs (OECD, 2009). Teachers should therefore be given the opportunity to gain a variety of competences, including those of knowledge development, research and critical thinking (EC, 2013; EU, 2009). It should, however, be stressed that the idea of encouraging teachers to conduct their own research is not new (Hammersley, 1993). Stenhouse (1975), for instance, argued that assumptions and habits acquired in the past constrain us, and that teachers should understand teaching as a process in which they learn how to improve their skills and capacities. Consequently, Stenhouse introduced teacher research as a concept for the professional development of teachers (Devetak \& Vogrinc, 2014) and as an important element of promoting teachers' professional development (Moutafidou, Melliou, \& Georgopoulou, 2012). Similarly, Valenčič Zuljan and Vogrinc (2010, p. 457) argue that teachers' competence in innovation and research is one of the fundamental conditions for significant changes in educational practice as a response to changes within society. Teachers should, through research, investigate the impact of interventions or explore the positive and negative effects of educational practice (BERA, 2014). In addition, Kanasanen (2014) stressed the role of research in integrating theory and practice, which are intrinsically connected and can be implemented by means of practitioner research and/or evidence-based practice. Admiraal, Smit and Zwart (2014, p. 1) claim that "teacher research is a way to bridge the gap between theory and teaching practice", which refers to: implementing research results in practice, using practice as a source of research problems, and cooperation between researchers and practitioners. Teachers' involvement in research (also known as practitioner research) is defined as a process in which teachers evaluate and reflect on their own teaching practice, its impact and the processes associated with teaching, using the appropriate methodology of educational research (Seberova, 2010).

The British Educational Research Association's Action and Research Centre (BERA-RSA, 2014) has prepared a report on teacher education in the United Kingdom identifying four main areas in which research can contribute to teacher education: (i) the content of initial teacher education (ITE) programmes should be derived from research-based knowledge, (ii) the structure and delivery of ITE programmes should consider research findings with regard to the role of research in ITE programmes, (iii) teachers and teacher 
educators should be competent in both conducting research and using research findings, and (iv) teachers and teacher educators should be researchers of their own practice.

BERA (BERA-RSA, 2014) stresses that both schools and faculties delivering ITE programmes need to become research-rich environments in which teachers and researchers work in partnership rather than conducting their work as completely separate entities. The report also emphasises that researchrich schools and universities or colleges offering initial teacher education programmes are the hallmark of high-performing education systems, and that teachers and teacher educators need to engage in research to keep abreast of the latest advances in their academic field and to progress in education. In order to do so, they need to be properly equipped to engage in research, which means having the capacity, motivation, confidence and opportunity to do so. Teacher research competence needs to be sustained during initial teacher education programmes and throughout teachers' professional careers, thus leading to an understanding of research as a normal element of teaching and learning.

In summary, by conducting research, teachers research their own practice, on the basis of which they evaluate and improve their own work, which is an important element of their professional development. They also combine theory and practice, which can ultimately lead to significant changes in educational research and practice.

\section{The Role of Research in Initial Teacher Education}

In order to empower and inspire prospective teachers to commit to research, it is very important that they are made aware that conducting research on educational practice is one approach to establishing and ensuring the quality of such practice, and that they recognise research as an important factor in their professional development. It is therefore crucial that student teachers develop a basic understanding of research and gain some practical experience in it, with the aim of developing an understanding of the concept of practitioner research (Saquipi \& Vogrinc, 2016). The importance of equipping teachers with research competence has also been recognised by the OECD (2011), which has suggested that undergraduate research is a means of addressing the challenge of developing the necessary competences for a demanding profession. Undergraduate research within ITE programmes should thus enable (prospective) teachers to become innovators and researches. This requires teacher education that helps teachers to become innovators and researchers in education, laying a solid 
foundation for continuous learning and professional development (DarlingHammond \& Bransford, 2005).

Winch, Oancea and Orchard (2015) argue that teacher education must enable a positive relationship between educational research, on the one hand, and teaching knowledge and practice, on the other. In contrast to understanding the teaching profession as a craft, understanding teaching as a researchbased profession emphasises the fact that professional knowledge and practice are complementary elements of the profession and professional development. Teaching requires practical knowledge and skills, a knowledge and understanding of concepts and conceptual frameworks in education, and an ability to critically analyse and interpret existing knowledge based on reflection on one's own practice within the framework of broader research findings (Krokfors et al., 2011). Winch, Oancea and Orchard (2015) emphasise that in principle, research can be enriched and can enrich teacher professional knowledge, but that the question of how to build this relationship into teacher education programmes remains a considerable practical challenge. As Smith (2015) argues, policymakers and teacher educators often use the term research-based, which is defined on the following basis (Krokfors et al., 2011): (i) the structure of ITE programmes is based on a detailed analysis of education, (ii) all teaching is research-based, (iii) student teachers engage in activities in which they practise reasoning, decision making and explanation with regard to various pedagogical issues, and (iv) the acquisition of research competence is one of the goals of ITE programmes. However, student teachers are often consumers of research and are seldom expected to be producers of research (Smith, 2015).

Gomez (2013), Munthe and Rogne (2014) argue that the role of research in initial teacher education is still unclear. The understanding of what initial teacher education research is and the methods for involving students in undergraduate research vary between disciplines, colleges and universities. Munthe and Rogne (2014) stress that undergraduate research is a means to qualify prospective teachers for professional learning and innovation; however, there is still little knowledge about how ITE programmes address research for students. ITE programmes are formed based on different organisational structures that are historically, culturally and socially produced, as well as dependent on political streams. Furthermore, the structure, conceptualisation and operationalisation of the programmes differ by country (Craig, 2016).

In the context of the role of research in ITE, Flores (2016) reported that analyses of ITE curriculum plans illustrate a diversity of ways of including research in teacher education programmes, as well as ways of integrating it into practice and coursework. Overall, in Europe and elsewhere, research 
components vary: in some cases they are not present, while in others they are not explicit in the ITE curriculum, as the decision to develop student teachers' competence is made by higher education institutions; in yet other cases, an explicit curriculum unit on research methods is included.

Flores (2016) strongly suggests further developments in improving the research dimension within the ITE curriculum in a more explicit and articulated way, according to the following two main aims: (i) a concept of professional development that underpins student teachers' involvement in research projects, thus enabling them to gain experience in research, and (ii) the training of prospective teachers in research methods.

\section{Models of Including Research in Initial Teacher Education}

It is clear that the main objective of ITE programmes is not to educate researchers or teacher-researchers, but to impart an attitude towards teaching (Toom et al., 2010). The authors claim that research-based teacher education develops autonomous teachers who are able to make theory-based decisions and to use and produce research. The decision of (not) providing a researchbased ITE programme depends on various historical, social, cultural, political and conceptual factors (Munthe \& Rogne, 2015). One important factor is considered to be the degree to which higher education institutions (HEIs) delivering ITE are involved in research for which their faculty members possess genuine experience and training. This also affects accreditation standards. Healey and Jenkins (2009) presented a model of four key factors that need to be present in an ITE programme if the programme is to recognise the role of undergraduate research. 


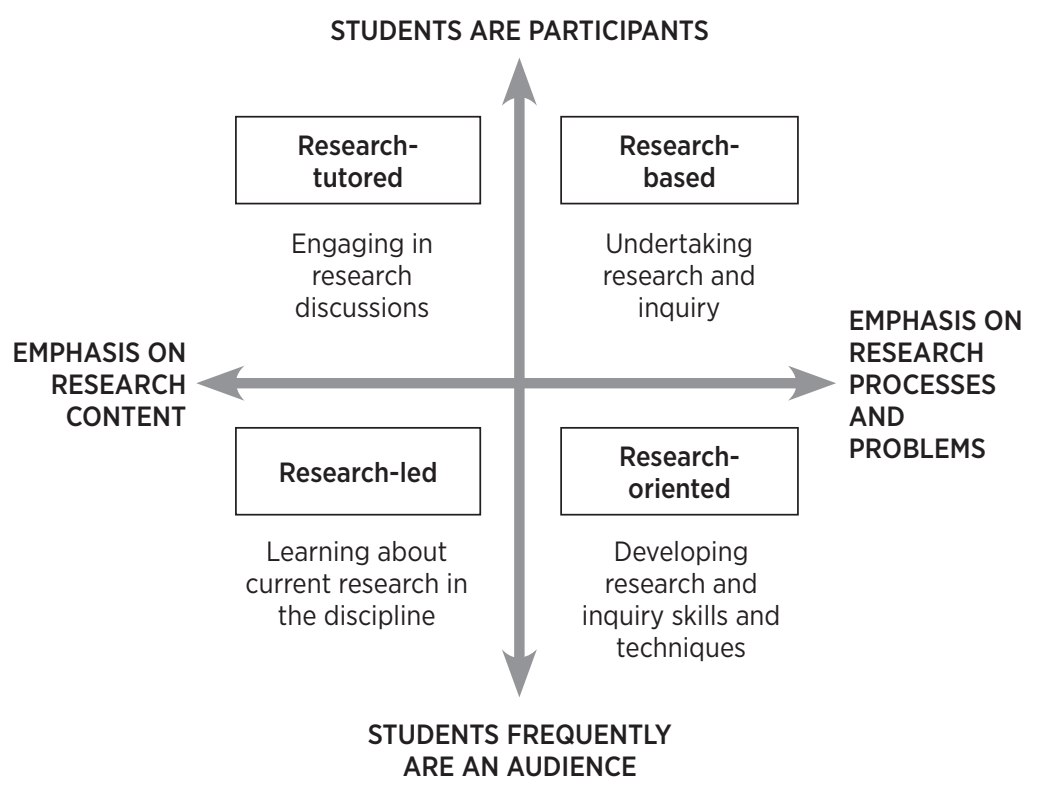

Figure 1. The nature of undergraduate research. Adapted from Healey \& Jenkins, 2009, p. 7.

In the model above (Figure 1), four areas for research in education are presented: research-tutored, research-based, research-led and research-oriented. These areas are separated by two axes, indicating that ITE programmes can either be more focused on research content or on research processes and problems, and that student teachers can be seen either as the audience or as active participants in research. The research-tutored approach means that students are active agents of research and are usually engaged in activities such as writing and discussing research papers. Another area in which students are active in research is the research-based area, where students engage in research-based learning. On the other hand, there are two areas where students are often the audience. The research-led area means that student teachers learn about current research on the relevant issues within the discipline. Within the researchoriented area, student teachers develop research and inquiry competence.

The model provides four areas for research in education, all of which are considered to be part of research-based teacher education. All four areas are valid, and they should all be present in research-based teacher education. In general, research-based teacher education means that students carry out research in their courses independently and with an open outcome, thus enabling them to internalise and practise research approaches and methods, including 
the skills of formulating precise questions and processing and monitoring the research process.

Saqipi \& Vogrinc (2016, p. 111) outlined the following framework for developing research competence within ITE:

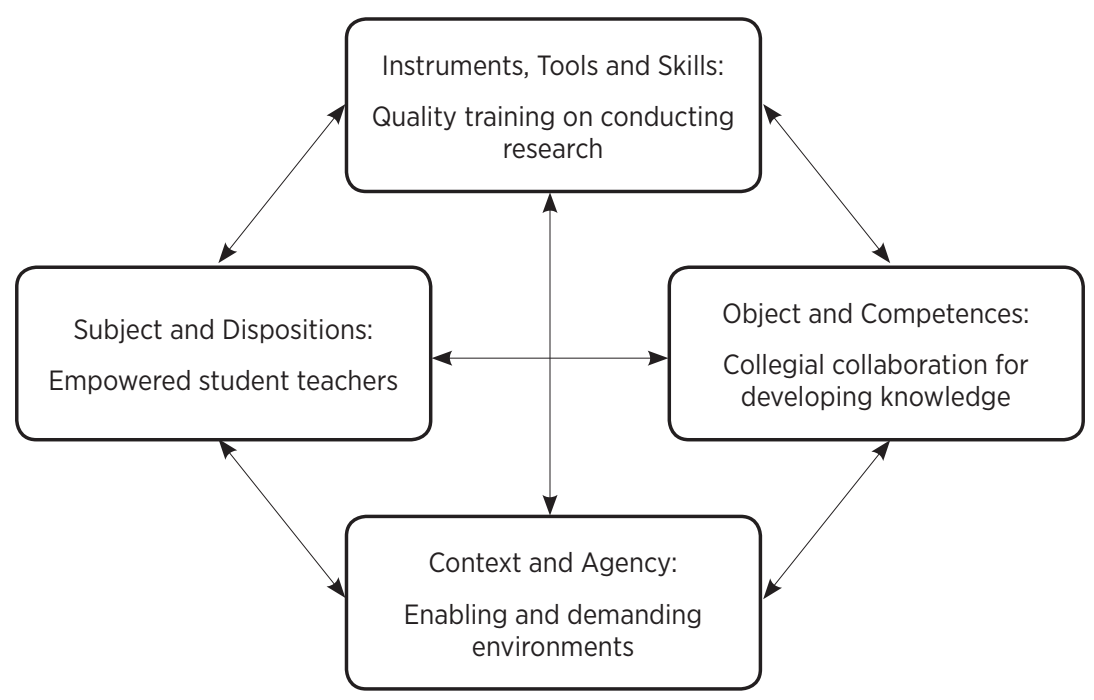

Figure 2. Framework for developing student teachers' research competence.

Adapted from Saqipi \& Vogrinc, 2016, p. 111.

The model encompasses the need to ensure competent student teachers who become both committed to and skilled in carrying out educational research through cooperating with other student teachers and by being confronted with a demanding work environment (Saquipi \& Vogrinc, 2016). Both models (Healey \& Jenkins, 2009; Saquipi \& Vogrinc, 2016) highlight the importance of ITE programmes in developing student teachers' research competence, and they both point out the importance of empowering student teachers to perform their own research and/or develop their own knowledge together with other students.

\section{Initial Teacher Education in Slovenia}

According to the Rules on Training Teachers and Other Professionals in Primary Education (2015), the Rules on Training Teachers and Other Professionals in Comprehensive Education (2015) and the Rules on Training Teachers and Other Professionals in Vocational Education (2012), primary and 
secondary school teachers in Slovenia must obtain a master's level of formal education, but they can choose different educational paths to acquire the appropriate qualification. Future teachers can engage in ITE programmes and concurrent programmes that are usually offered by faculties of education and certain other multidisciplinary faculties (e.g., the Faculty of Arts, the Faculty of Mathematics, etc.). Future generalist teachers (which refers to teachers qualified to teach grades 1-5 of primary school) study at faculties of education. These faculties also perform some programmes for subject specialist teachers, who are qualified to teach grades 6-9 of primary school. The majority of subject specialist teachers are trained at multidisciplinary faculties and qualified for teaching in secondary schools and grades 6-9 of primary school. By attending these concurrent programmes, teachers acquire specific subject knowledge, teaching-related skills and teaching experience (through a system of school placement). The other alternative is a consecutive programme in which teacher candidates can first acquire a non-pedagogical degree from one of a range of faculties and then attend a one-year programme designed to empower them with pedagogical competences. This programme, pedagogical-andragogic education (PAE), consists of 60 European Credit Transfer and Accumulation System (ECTS) credits and focuses on pedagogy, general didactics, subject-specific didactics, developmental and educational psychology, educational research, and practical work with students. Candidates can take the programme at faculties of education, the Faculty of Arts and the Faculty of Mathematics. This path is only an option for subject specialist teachers and is not intended for generalist teachers, who are only educated at faculties of education.

Until recently, ITE programmes in Slovenia were prepared based on the Standards for Accreditation of Initial Teacher Education Programmes (2011). These standards specified the scope of pedagogical training within the ITE study programme. ITE programmes had to include pedagogical-psychological knowledge, which encompassed psychology, pedagogics, didactics, andragogy, educational research, and humanities and social sciences knowledge, including philosophy, sociology and anthropology, as well as courses or special didactics related to the study of the primary discipline and at least 15 credits of school placement. However, the Standards were dropped in 2018 and there are currently no valid standards on which new ITE programmes must be based. In the process of accreditation, the programmes are evaluated by a group of at least three trained and licenced experts assigned by the Slovenian Quality Assurance Agency for Higher Education (SQAA). For the purposes of accreditation, the composition and content of the study programme and the concept of its delivery are examined (SQAA, 2018). Prior to final accreditation, the SQAA 
acquires the opinion of the Ministry of Education, Science and Sport (Eurydice, 2019). Each study programme consists of various elements, including the aims of the programme, the proposed competences, and the courses that would be taught within the study programme. The courses are also weighed in terms of the ECTS, which represents learning based on defined outcomes and their associated workload. Typically, 6o ECTS credits are the equivalent of a full year of study, and the credits are broken down into several smaller units. The first cycle (undergraduate) degree usually consists of either 180 or 240 ECTS credits, and the second cycle (postgraduate) degree is equal to 90 or 120 ECTS credits (European Commission, n. d.). The curriculum of each study programme represents an important basis for delivering the programme, but it also reflects the conceptualisation of the programme and the importance given to the various fields within each study programme, as well as referring to the question of recognising educational research as an (important) element of ITE programmes.

\section{Research Problem and Aims}

Derived from (i) recognition of the importance of undergraduate research $(\mathrm{OECD}, 2011)$ as a means of addressing the challenge of developing the necessary competence, (ii) the fact that there is still little knowledge about how ITE programmes address research for students, and (iii) the question of how the conceptualisation and operationalisation of teacher research can be further advanced to better serve the current contexts and realities of national and transnational policy contexts (Saqipi \& Vogrinc, 2019), the present study was undertaken with the aim of providing a systematic insight into the research components within ITE in Slovenia. According Flores (2016), insight into research components within ITE curriculum plans is the starting point for further developments in improving the research dimension in the training of future teachers.

Following this main aim, the following research questions were designed:

a) Is the research component reported in the proposed competences of the programme and how is articulated?

b) Is the course educational research included in the ITE programme and what content is proposed in the syllabi?

c) How is the educational research course (or courses) embedded in the ITE programme and evaluated by means of the ECTS? 


\section{Method}

The aim of the study was addressed using mixed-methods research. A parallel mixed-methods design was used, which is a type of design in which "the researcher converges and merges quantitative and qualitative data in order to provide a comprehensive analysis of the research problem" (Creswell, 2014, p. 15). According to Mayring (2001), as cited in Mažgon (2008), a mixed-methods study can be conducted on five different levels, ${ }^{2}$ and one of them, the data level, was used in the present study. The data level of integrating quantitative and qualitative research proposes qualitative analysis as a basis for the formation of categories. Once the categories are formulated, they are analysed statistically, mainly within the framework of descriptive statistics (e.g., frequencies and/or percentages).

The data collection was based on purposefully selected (Creswell, 2014, p. 189) documents, i.e., ITE programme curricula and syllabi of educational research courses, as it was determined that these data would correspond to the aims of the study. The documents were collected for all 13 faculties in Slovenia, which offer a total of 19 bachelor ITE programmes and 78 master's ITE programmes (Ministry of Education, Science and Sports of the Republic Slovenia, 2018). It is important to stress that only curricula and syllabi available on the official websites of all of the faculties delivering ITE programmes were taken into consideration.

Data analysis was carried out in accordance with the aims of the research. In order to determine whether the competence of educational research is included in each individual ITE programme, we first analysed the listed competences of each ITE programme, also with regard to whether the curriculum of a bachelor or master's ITE programme was being considered. The results of this part of the analysis are presented in Table 1 , which contains the frequencies and percentages of ITE programmes according to two variables: (i) the reported research competence (or its absence), and (ii) the level of the ITE programme. We also tried to formulate some common elements of each research competence and present how the competence can be articulated in general for bachelor and master's programmes.

The curricula of ITE programmes were also reviewed and analysed with the aim of identifying whether an educational research course (or courses) is included in each individual ITE programme, taking into account the level of ITE programme. The results are presented in Table 2, in which frequencies and

2 Mayring (2001, as cited in Mažgon, 2008, p. 51-54) defined five different levels of integrating quantitative and qualitative research: the technical level, the data level, the level of individuals, the model level, and the level of common research logic. 
percentages are included according to the inclusion (or exclusion) of an educational research course and the level of the ITE programme. Furthermore, we analysed the content of the syllabi of the educational research course(s). Since the syllabi differ substantially in articulating the relevant content - some contain very detailed descriptions, while others focus on certain main concepts (albeit encompassing many sub-concepts) - we were not able to conduct precise systematic analyses, so we aimed instead to detect the most common elements of the content.

With the aim of determining how educational research courses are embedded in the ITE programme (evaluated by means of the ECTS), we looked for information about the credit loadings of the educational research course(s) within each ITE programme. In cases where there were multiple courses, we summed the credits of two, or in some cases even more, courses within the programme. The results are presented in Table 3, which shows the different ECTS loadings according to the level of the ITE programme.

\section{Results}

We first present the results of the analysis aimed at identifying whether research competence is proposed as one of the competences student teachers should acquire during ITE. We then focus on the results showing the presence of courses related to educational research. Finally, we present how educational research is embedded in ITE programmes in the sense of ECTS credits.

\section{Research competences as reported in the proposed ITE competences}

Table 1

Research components within the proposed ITE competences

\begin{tabular}{lcccccc}
\hline & \multicolumn{2}{c}{$\begin{array}{c}\text { Research competences } \\
\text { reported }\end{array}$} & $\mathbf{f}$ & $\mathbf{f} \%$ & $\begin{array}{c}\text { Research competences } \\
\text { not reported }\end{array}$ & \multicolumn{2}{c}{ Total } \\
\cline { 2 - 7 } & 13 & 13.4 & 6 & $\mathbf{f} \%$ & $\mathbf{f}$ & $\mathbf{f} \%$ \\
\hline Bachelor & 32 & 32.9 & 46 & 47.4 & 78 & 19.6 \\
Master's & 45 & 46.6 & 52 & 53.6 & 97 & 100 \\
\hline Total & & & & & \\
\hline
\end{tabular}

Overall, the results in Table 1 show that students are expected to acquire research competence in less than half (46.6\%) of all bachelor and master's ITE programmes. Closer analysis shows that the acquisition of research competence 
is one of the aims in about two thirds (13 out of 19) of bachelor ITE programmes and in less than half of master's ITE programmes. Based on these results, we can conclude that in more than half of ITE programmes, student teachers are not expected to gain research competence, a result that is even more evident in master's ITE programmes.

As well as aiming to identify whether the programme envisages research competence, the research competence analysis also sought to determine how this competence is articulated. According to the proposed competences, it was determined that in bachelor programmes, students are mainly expected to develop the ability to carry out educational research based on the ability to use research methodology, methods, data gathering and processes, along with the ability to present and interpret results. In master's programmes, students are expected to develop the ability to use research in support of professional development by researching one's personal practices, performing self-evaluation studies, thinking critically about one's work, and developing one's own practice.

The analysis indicates that there are still many student teachers who are not provided with either the opportunity or the obligation to acquire research competence. This is one of the most important competences, as it enables future teachers to develop critical thinking, leading to the critical scrutiny of their own practice and to professional development.

\section{Educational research as a compulsory course within ITE}

With the aim of identifying whether a course (or courses) related to educational research is part of each of the ITE programmes taught in Slovenia, we analysed all of the available curricula descriptions. The analysis showed that there are various names for the courses aimed at empowering future teachers with research competence, e.g., Educational Research, Educational Methodology, Scientific Research Methodology, Research of the Educational Process, Research of Educational Practice, and An Introduction to Educational Research. In general, the results show that more than half of ITE programmes include educational research as a compulsory course. Specifically, Educational Research, as a compulsory course, is an element of the majority of bachelor ITE programmes, whereas only half of all master's ITE programmes (remembering that a master's level degree is required) include this course. 
Table 2

Educational research as a compulsory course within ITE

\begin{tabular}{lcccccc}
\hline & \multicolumn{2}{c}{$\begin{array}{c}\text { Educational Research } \\
\text { Course }\end{array}$} & \multicolumn{2}{c}{$\begin{array}{c}\text { No Educational Research } \\
\text { Course }\end{array}$} & \multicolumn{2}{c}{ Total } \\
\cline { 2 - 7 } & $\mathrm{f}$ & $\mathrm{f} \%$ & $\mathrm{f}$ & $\mathrm{f} \%$ & $\mathrm{f}$ & $\mathrm{f} \%$ \\
\hline Bachelor & 18 & 18.6 & 1 & 1.4 & 19 & 19.6 \\
Master's & 39 & 40.2 & 39 & 40.2 & 78 & 80.4 \\
\hline Total & 57 & 58.8 & 40 & 41.2 & 97 & 100 \\
\hline
\end{tabular}

The analysis also showed that courses related to educational research are included in all bachelor and master's ITE programmes delivered at all three faculties of education in Slovenia, but in less than half of ITE programmes at all three faculties of arts (which also deliver some ITE programmes). The percentage of ITE programmes containing a course (or courses) related to educational research is even smaller at other faculties, and at some faculties there is no research-related course within the ITE programme.

The analysis of the syllabi of the courses related to research shows that these courses in bachelor ITE programmes mainly propose the following content: research ethics, quantitative research, qualitative research, different research designs (e.g., action research, case study, life history), the research process, defining aims, designing hypotheses, data collection techniques, data processing with SPSS, presenting and interpreting results, conducting research on a basic level, writing a research report, statistics (basic statistical concepts: population, sample and sampling, variables), descriptive statistics (mean, standard deviation, distribution), inferential statistics (correlation, null hypothesis), and self-evaluation.

The results of the analysis of master's ITE programmes indicate that master's courses related to research can be divided in two groups according to content. The first group comprises courses that are delivered at the faculties of education (as part of master's programmes) and pedagogy and andragogy programmes delivered at faculties of arts. The content of these programmes proposes that students shall upgrade and deepen the knowledge acquired within bachelor programmes. The following content is proposed: planning and implementing more complex research procedures, conducting research independently and preparing professional and scientific articles, using more complex statistical procedures (e.g., non-parametric tests, regression, etc.), criteria for quality of research, critical use of results, research as a means of innovating one's own practice, and preparing the master's thesis. 
The second group includes courses related to research that are delivered within ITE programmes at other faculties and whose proposed content is largely similar to the content of courses within the bachelor programmes analysed earlier. These results indicate that students enrolled in these programmes are not expected to acquire the competence to become researchers of their own practice, but only to have some basic knowledge of educational research.

It must be stressed that it would be incorrect to claim that the programmes that do not include any courses related to educational research do not develop the research competence of their students. Research competence can also be developed within another course (or courses) that is, for instance, oriented towards student teachers studying various topics within which they are expected to perform some small-scale research related to the field of the course. It should be emphasised that although this kind of approach equips student teachers with some knowledge of carrying out research, a systematic approach based on courses related explicitly to carrying out the process of educational research should be an important element of every ITE programme.

Based on the results of course presence (Table 2), further analysis determined the ITE programmes in which a course (or courses) aimed at empowering future teachers with research competence was clearly identified.

Table 3

Credit loadings of educational research within ITE programmes

\begin{tabular}{lccc}
\hline $\begin{array}{l}\text { Number of ECTS credits per course } \\
\text { related to educational research }\end{array}$ & Bachelor & Master's & Total \\
\hline 3 & 3 & 1 & 4 \\
4 & 3 & 10 & 13 \\
5 & 2 & 4 & 6 \\
6 & 4 & 21 & 25 \\
7 & 1 & 2 & 3 \\
9 & 2 & 2 & 4 \\
10 & 3 & 1 & 4 \\
\hline
\end{tabular}

As is evident from Table 3, the number of ECTS credits for educational research varies considerably: the minimum number of ECTS credits is 3 , and the highest number is 10. The most common ECTS credit weighting, for both bachelor and master's programmes, is 6 ECTS credits. There is also a large proportion of postgraduate programmes that require 4 ECTS credits. The ECTS weighting of the course is an important indicator not only for determining the 
quantity of time student teachers have for developing their research competence, but also in the context of how different content within the course can be delivered, elaborated and acquired, as well as the extent to which research competence can be developed within a certain ITE programme.

\section{Discussion}

The main aim of the present paper was to identify the role of research in ITE programmes in Slovenia and to establish a basis for further research that would establish a conceptual overview. By analysing ITE curricula, we discovered that in more than half of ITE programmes, students' attainment of research competence is not a goal. However, a breakdown of the results shows that two thirds of bachelor ITE programmes and less than half of master's ITE programmes include the aim of students acquiring research competence. The aim of bachelor programmes is for students to acquire the competence to perform basic educational research, whereas master's programmes focus more on utilising educational research as a means of professional development. The analyses of curricula show that with the exception of one programme, all bachelor ITE programmes include an obligatory course concerning educational research. In the case of master's programmes, however, it was established that only half of them include a course (or courses) related to educational research. Furthermore, the analysis of syllabi content shows that both bachelor and master's programmes delivered at other faculties aim for the students to acquire basic research knowledge, whereas master's programmes delivered at faculties of education, as well as pedagogy and andragogy programmes delivered at faculties of arts, seek to empower their students to conduct more complex research, often with the aim of improving their own practice.

The fact that research competence can also be developed within other courses certainly cannot be overlooked. However, if research is only a (minor) part of a course focused predominantly on developing other competences, students' research competence will not be assessed, whereas it is subject to formal assessment when research is the course topic. Furthermore, educational research courses need to be linked to other courses to enable students to apply various research methodologies to different content and content aims.

The analysis of the ECTS credits attributed to educational research courses suggests a variety of solutions, which also indicates a very different role or appreciation of educational research in different ITE programmes and by the educators who have designed them.

In general, the results indicate that bachelor ITE programmes, in 
comparison to master's ITE programmes, place more emphasis on equipping prospective teachers with research competence. Bearing in mind that student teachers have to obtain a master's degree, it would be expected that master's study programmes would focus on educational research to a larger extent. Another issue that needs to be considered in this context is the entry conditions for master's programmes. In some master's ITE programmes, completion of a previous course in educational research is a requirement for admission, but not in all programmes. Thus, many different options are possible: some student teachers go through the process of gaining research competence in both bachelor and master's ITE programmes, some only in bachelor programmes, some only in master's programmes, and some not at all. As argued by Saquipi and Vogrinc (2016), teacher education in research should be seen as a continuum that starts at the bachelor level of studies and continues at the master's level. Later, those student teachers who do have the opportunity to gain research competence within courses related to educational research will not all have the same opportunities, as the load of ECTS credits varies greatly across ITE programmes in Slovenia. Some student teachers will only be able to acquire the basics, while others will be able to become highly competent researchers of their own practice. The results of the present study thus confirm findings (Flores, 2016) that suggest there are diverse ways of including research competence in ITE programmes. It could therefore be suggested that ITE programmes in Slovenia are not consistent in following and supporting this already recognised idea (OECD, 2011; Saquipi \& Vogrinc, 2016).

\section{Conclusion, Limitations and Further Research}

The results of this study indicate a strong need for universities and educators, as well as policymakers in the field, to reconsider the role of educational research in teachers' everyday practice. They should also recognise and realise the importance of equipping prospective teachers with research competence, which is considered to be an important element of changing teachers' practice, of linking theory and practice, and of supporting teachers' professional development. Inevitably, research competence should be included in the proposed competences of every ITE programme and realised through courses dedicated directly to the subject of educational research.

Regarding the models proposed by Healey and Jenkins (2009) and Saqipi and Vogrinc (2016) discussed earlier and the findings of the present study, the main efforts in initial teacher education in Slovenia should be directed towards the following issues. 
- Insisting on including educational research courses in all initial teacher programmes at all faculties delivering these programmes, thus providing student teachers with quality training on conducting research.

- Building and following the concept of the two-step model of developing research competence in teacher education: the basic level (bachelor ITE programmes) and the advanced level (master's ITE programmes). This model would also assume an obligatory differential exam for master's programmes for students who have not acquired basic educational research knowledge within their previous studies.

- It is also necessary to make a shift from the prevailing concept of student teachers as an audience of teacher research to the concept of student teachers as participants. Students should have more opportunities to gain experience in undertaking research individually or with their peers, which would also lead to more critical use of research results and would enable future teachers to internalise the research approach. This shift could be realised by including student teachers in research projects to a larger extent.

It should be emphasised that the present study was intended to represent a starting point for researching the conceptual structure of ITE programmes in Slovenia and further research on the topic needs to be conducted. Furthermore, the study is based on an analysis of the teacher education curricula and syllabi that were available on the official websites of faculties delivering ITE programmes. Considering the main aim of the study, i.e., to provide a systematic insight into the research components within ITE in Slovenia, the design is fairly strong, although the results are based on declared descriptions. The issue of the role of research elements in ITE can nonetheless be studied in several ways, and a follow-up using another methodology (e.g., focus groups with teacher educators, student teachers, teachers, policymakers, developers of ITE programmes, or using questionnaires with different stakeholders) would be advisable.

Future research issues could include the operationalisation of educational research within ITE, the analysis of syllabi realisation, the question of including student teachers in research projects, and research on teachers' research competence and their attitude towards the concept of the teacher as a researcher. 


\section{References}

Admiraal, W., Smit, B., \& Zwart, R. (2014). Models and design principles for teacher research. IB Journal of Teaching Practice, 2(1), 1-7.

BERA-RSA [The British Educational Research Association's Action and Research Centre]. (2014). Research and the teaching profession: Building the capacity for a self-improving system. Final report of the BERA-RSA inquiry into the role of research in teacher education. BERA-RSA Inquiry into Research and Teacher Education.

Creswell, J. (2014). Research Design. Qualitative, quantitative, and mixed methods approaches. Sage. Craig, J. C. (2016). Structure of teacher education. In J. Loughran \& M. L. Hamilton (Eds.), International book for teacher education (pp. 69-136). University of Houston.

Darling-Hammond, I., \& Bransford, J. (2005). Preparing teachers for a changing world: What teachers should learn and be able to do. John Wiley \& Sons.

Devetak, I., \& Vogrinc, J. (2014). A PROFILES model of science teachers' professional development, a Slovenian perspective of implementation of action research. In C. Bolte, J. Holbrook, R. MamlokNaaman, \& F. Rauch (Eds.), Science teachers' continuous professional development in Europe: Case studies from the PROFILES project (pp. 182-188). Freie Universität Berlin \& Alpen-Adria-Universität Klagenfurt. http://www.profiles-project.eu/Dissemination/PROFILES_Book/PROFILES_book2.pdf?1407394633 EC [European Commission]. (2013). Supporting teacher competence development for better learning outcomes. http://ec.europa.eu/assets/eac/education/experts-groups/2011-2013/teacher/teachercomp_en.pdf EC [European Commission]. (n. d.). European credit transfer an accumulation system (ECTS). https:// ec.europa.eu/education/resources-and-tools/european-credit-transfer-and-accumulation-system-ects_en EU [European Union]. (2009). Council Conclusions of 26 November 2009 on the professional development of teachers and school leaders. https://eur-lex.europa.eu/LexUriServ/LexUriServ.do?uri $=\mathrm{OJ}: \mathrm{C}: 2009: 302: 0006: 0009: \mathrm{EN}: \mathrm{PDF}$

Eurydice. (2019). Initial Education for Teachers Working in Early Childhood and School Education https://eacea.ec.europa.eu/national-policies/eurydice/content/initial-education-teachers-workingearly-childhood-and-school-education-76_en Flores, M. A. (2016). Teacher education curriculum. In J. Loughran \& M. L. Hamilton (Eds.), International handbook of teacher education (pp. 187-230). Springer Press.

Flores, M. A. (2017). Practice, theory and research in initial teacher education: International perspectives. European Journal of Teacher Education, 40(3), 287-29o.

Gomez, M. (2013). Incorporating undergraduate research methods topics into a content based course: A preliminary case study. Insights to a Changing World Journal, 3, 69-81.

Hammersley, M. (1993). On the teacher as researcher. Educational Action Research, 1(3), 425-445. https://doi.org/10.1080/0965079930010308

Healey, M., \& Jenkins, A. (2009). Developing students as researchers. Special Publication, No. 1. In S. K. Haslett \& H. Rowlands (Eds.), Proceedings for the Newport NEXUS Conference (pp.7-11). Centre for Excellence in Learning and Teaching. 
Kansanen, P. (2014). Teaching as a master's level profession in Finland: Theoretical reflections and practical solutions. In O. McNamara, J. Murray, \& M. Jones (Eds.), Workplace learning in teacher education. International practice and policy (pp. 279-292). Springer.

Krokfors, L., Kynäslahti, H., Stenberg, K., Toom, A., Maaranen, K., Jyrhämä, R., ... Kansanen, P. (2011). Investigating Finnish teacher educators' views on research-based teacher education. Teaching Education, 22(1), 1-13. https://doi.org/10.1080/10476210.2010.542559

Mažgon, J. (2008). Razvoj akcijskega raziskovanja na temeljnih postavkah kvalitativne metodologije [The development of action research on the basic assumptions of qualitative methodology]. UL Filozofska fakulteta.

Ministrstvo za izobraževanje, znanost in šport Republike Slovenije [Ministry of Education, Science and Sports of the Republic Slovenia] (2017). Analiza področja za izvedbo javnega razpisa "Inovativne in prožne oblike poučevanja in učenja v pedagoških študijskih programih [An analysis of the field for the needs of the public call "Innovative and flexible teaching and learning in initial teacher education programmes"]. https://www.gov.si/drzavni-organi/ministrstva/ministrstvo-za-izobrazevanjeznanost-in-sport/javne-objave/?tx_t3javnirazpis_pi1\%255Bshow_single\%255D=1528 Moutafidou, A., Melliou, K., \& Georgopoulou, A. A. (2012). Educational research and reacher development. Procedia-Social and Behavioural Sciences, 31, 156-161.

Munthe, E., \& Rogne, M. (2014). Research based teacher education. Teaching and Teacher Education, 46(1), 17-24.

OECD [Organisation for Economic Co-operation and Development]. (2009). Creating effective teaching and learning environments. First results from TALIS. OECD Publications. http://www.oecd. org/dataoecd/17/51/43023606.pdf

OECD [Organisation for Economic Co-operation and Development]. (2011). Building a high-quality teaching profession, lessons from around the world. Retrieved from: http://www2.ed.gov/about/inits/ ed/internationaled/ background.pdf

Rules on training teachers and other professionals in primary education. (2015). Slovenian Official Gazette (75/15).

Rules on training teachers and other professionals in comprehensive education. (2015). Slovenian Official Gazette (75/15).

Rules on training teachers and other professionals in vocational education. (2012). Slovenian Official Gazette (92/12).

SQAA [Slovenian Quality Assurance Agency for Higher Education]. (2018). https://www.nakvis.si/ wp-content/uploads/2019/05/NAKVIS_brosura_EN_web.pdf

Standards for Accreditation of Initial Teacher Education Programmes. (2011). http://pisrs.si/Pis.web/ pregledPredpisa?id=MERI 41

Saquipi, B., \& Vogrinc, J. (2016). Developing research competence in pre-service teacher education. Pedagoška obzorja-Didactica Slovenica, 31(2), 101-117.

Saquipi, B., \& Vogrinc, J. (2019). Call for papers: Development of teacher research as a form of developing teacher pedagogical practice. https://ojs.cepsj.si/index.php/cepsj/announcement/view/8 
Stenhouse, L. (1975). An introduction to curriculum research and development. Heinemann. Smith, K. (2015). The role of research in teacher education. Research in Teacher Education, 5(2), $43-46$.

Toom, A., Kynaslahti, H., Krokfors, L., Jyrhama, R., Byman, R., \& Stenberg, K. (2010). Experiences of a research based approach to teacher education: Suggestions for future policies. European Journal of Education, 45(2), 331-344

Valenčič Zuljan, M., \& Vogrinc, J. (2010). The factors of encouraging teacher innovation from the perspective of teachers and headmasters. In M. Valenčič Zuljan \& J. Vogrinc (Eds.), Facilitating effective student learning through teacher research and innovation (pp. 455-471). UL Faculty of Education. Winch, C., Oancea, A., \& Orchard, J. (2015). The contribution of educational research to teachers' professional learning: Philosophical understandings. Oxford Review of Education, 41(2), 202-216. https://doi.org/10.1080/03054985.2015.1017406

\section{Biographical note}

Tina ŠTEMBerger, $\mathrm{PhD}$, is an associate professor in the field of Educational Research Methodology at the Faculty of Education, University of Primorska. Her main research interests are predominantly trends in current research methodology challenges, doing research by actively involving children and linking research with educational practice. Her research work covers also topics as inclusive education, teacher competence, teacher development, teacher educators, ICT in education and entrepreneurial competences. 